\title{
Reduction of Synthetic Fertilizer for Sustainable Agriculture: Influence of Organic and Nitrogen Fertilizer Combination on Growth and Yield of Green Mustard
}

\author{
Zainal Muktamar", Dora Putri ${ }^{*}$, Nanik Setyowati ${ }^{*}$ \\ \# Soil Science Department, University of Bengkulu, Bengkulu 38371, Indonesia \\ E-mail: muktamar1959@yahoo.com \\ * Agronomy Department, University of Bengkulu, Bengkulu 38371, Indonesia \\ E-mail:doraputri.web@gmail.com;nanik_srg@yahoo.com
}

\begin{abstract}
Organic fertilizer is capable to decrease the use of synthetic fertilizer due to release of plant nutrients and improvement of other soil properties. The objective of this experiment was to compare the growth and yield of green mustard as affected by cattle manure and litter compost. The experiment was conducted employing Completely Randomized Design with 8 treatments. Treatments included litter compost and cattle manure at rate of $25 \mathrm{Mg} \mathrm{ha}^{-1}$ and $15,20,25 \mathrm{Mg} \mathrm{ha}^{-1}$ with addition of $1.85 \mathrm{~g}$ nitrogen fertilizer per plant, respectively. Each treatment was replicated 5 times. Soil used in this experiment was Ultisol collected at depth of 0-20 cm. Five $\mathrm{kg}$ of soil was mixed with organic fertilizer according to each treatment and placed in $10 \mathrm{~kg}$ polybag. Green mustard was planted to each polybag. Nitrogen fertilizer was applied a week after planting. The experiment revealed that application of litter compost and cattle manure at rate $25 \mathrm{Mg} \mathrm{ha}^{-1}$ with additional nitrogen fertilizer resulted in higher green mustard fresh weight per plant and number of leaves. On the other hand, application of both organic fertilizers at rate of $25 \mathrm{Mg} \mathrm{ha}^{-1}$ without addition nitrogen fertilizer as other treatments did not provide significant differences on most variables observed. This indicated that application of organic fertilizer is able to reduce synthetic nitrogen fertilizer for green mustard production.
\end{abstract}

Keywords — organic fertilizer; sustainable agriculture; green mustard.

\section{INTRODUCTION}

Modern agriculture has put application of synthetic fertilizer as essential input to increase productivity of agricultural land. At the same time, excessive use of pesticides also becomes necessary in agricultural practices. Study by [1] revealed that more than $40 \%$ vegetable farmers in Rejang Lebong, Bengkulu, Indonesia applied pesticides 6-15 times a week. Most of them were ignorant of having protective equipment during pesticide application. As a result, clinical test confirmed that $22.5 \%$ of them had deterioration in liver or kidney function. Farmer has also become addicted to apply in-organic fertilizer higher than the recommendation from the authority. However, excessive use of synthetic fertilizer will hamper soil quality and fertility. Research conducted by [2] showed that nitrogen fertilizer application for a long period of time significantly decreased soil $\mathrm{pH}$, exchangeable $\mathrm{Ca}, \mathrm{Mg}$, and $\mathrm{K}$ as well as Cation Exchange Capacity (CEC).

Minimizing the accumulation of pollutants in agroecosystems and avoiding the use of toxic chemicals especially synthetic chemical pesticides and fertilizers in agricultural process are essential for healthy environment. Organic products as eco-friendly natural sources, are believed to be an alternative for sustainable agriculture development. Application of organic waste materials is common practice to achieve higher agriculture production. The impact of organic agriculture on natural resources is favorable for interaction within the agro-ecosystem. This interaction is vital for both agricultural production and nature conservation. The current trend is to explore the possibility of supplementing synthetic fertilizers with organic ones since this agriculture practice is eco-friendly and cost-effective [3].

Application of organic fertilizer has weakness of low nutrient content, bulky, and slow release. Incorporating organic and synthetic fertilizers to soil would provide multiple benefits for improvement of soil chemical, physical and biological properties, leading to improved crop yield [3]. Organic fertilizers include but not limited to compost, farm yard manure, slurry, worm castings, urine, peat, green manure, dried blood, bone meal, fish meal, and feather meal. Inorganic 
fertilizers include but not limited to sodium nitrate, rock phosphate, limestone, ammonium nitrate, potassium nitrate, NPK fertilizers, muriate of potash, and supper phosphates [4]. Both organic and inorganic fertilizers provide nutrients for effective plant growth and development.

Integrated use of synthetic and organic fertilizers leads to development of sustainable crop production. This may improve the efficiency of synthetic fertilizers and thus reduce their use. Integrated use of organic and synthetic fertilizers is able to improve crop productivity and sustain soil quality and fertility [5]. Study by [6] showed that integrated use of organic wastes and synthetic fertilizers also improve crop yield, soil $\mathrm{pH}$, organic carbon and available $\mathrm{N}$, $\mathrm{P}$ and $\mathrm{K}$ in sandy loam soil. Other research resulted that application of compost along with synthetic fertilizers produced highest yield and maximum return. This treatment may also alleviate certain nutrient problems [7].

Reduction of synthetic fertilizer and use of organic fertilizer are necessary to return soil quality for sustainability of agriculture productivity. Application of organic fertilizer to soil is believed to improve its quality. Organic matter from organic fertilizer increased soil organic $\mathrm{C}$, total $\mathrm{N}$, available $\mathrm{P}$, available $\mathrm{K}, \mathrm{CEC}$, water holding capacity, and water infiltration rate, improved soil structure due to formation of micro-aggregates as well as reduced bulk density [8-14]. Improvement of soil quality due to application of liquid organic fertilizer was detected up to 25 $\mathrm{cm}$ from soil surface as reported by [15]. Study by [16] also showed that organic fertilizer was able to substitute nitrogen from synthetic fertilizer. Green mustard is among vegetable crops commonly grown to supply community consumption need.

Green mustard is a leafy vegetable commonly grown in the tropical region. It forms a high percentage of the daily intake of leafy vegetables [2]. Nitrogen is believed to be the primary limiting factor of green mustard cultivated in Ultisol; therefore, the effect of different sourced nitrogen fertilizer on its yield is necessary to be investigated. Soil in BengkuluIndonesia is dominated by Ultisol which mostly has low nitrogen content, leading to application of $\mathrm{N}$ fertilizer to increase its availability for plant growth. The importance of this fertilizer has increased over the year. Organic fertilizer as supplement is necessary to maintain or improve the soil fertility.

The objective of this experiment was to compare the growth and yield of green mustard as affected by cattle manure and litter compost combined with $\mathrm{N}$ fertilizer.

\section{MATERIALS AND METHODS}

\section{A. Experimental Design and Treatment}

The experiment was conducted in Semarang Village, Bengkulu, Indonesia, using acid soil of Ultisol. Composite soil sample was collected from 5 locations around the experimental site. Soil sample was air-dried and sieved through $5 \mathrm{~mm}$ mesh screen. Five $\mathrm{kg}$ of soil was mixed thoroughly with organic fertilizer according to each treatment a week before planting and put into $10-\mathrm{kg}$ polybag. Each experimental unit was randomly placed in approximately 250 $\mathrm{m}^{2}$ area. The area was freed from shading to provide sufficient light.
The experimental design was a completely randomized design (CRD) with eight treatments. Each treatment was replicated 5 times. The treatments were shown in Table I.

TABLE I.

RATE OF ORGANIC FERTILIZER AND NitRogen FERTILIZER AND ITS COMBINATION

\begin{tabular}{|c|c|}
\hline Treatment & Rate \\
\hline $\mathrm{LC}$ & Litter Compost 25 ton ha $^{-1}$ \\
\hline $\mathrm{LC} 15 / \mathrm{N}$ & Litter Compost 15 ton $\mathrm{ha}^{-1}+1.85 \mathrm{~g} \mathrm{~N}$ pot $^{-1}$ \\
\hline LC20/N & Litter Compost 20 ton ha ${ }^{-1}+1.85 \mathrm{~g} \mathrm{~N} \mathrm{pot}^{-1}$ \\
\hline $\mathrm{LC} 25 / \mathrm{N}$ & Litter Compost 25 ton $\mathrm{ha}^{-1}+1.85 \mathrm{~g} \mathrm{~N}$ pot $^{-1}$ \\
\hline $\mathrm{CM}$ & Cattle Manure 25 ton $\mathrm{ha}^{-1}$ \\
\hline CM15/N & Cattle Manure 25 ton $\mathrm{ha}^{-1}+1.85 \mathrm{~g} \mathrm{~N} \mathrm{pot}^{-1}$ \\
\hline $\mathrm{CM} 20 / \mathrm{N}$ & Cattle Manure 25 ton $\mathrm{ha}^{-1}+1.85 \mathrm{~g} \mathrm{~N}$ pot $^{-1}$ \\
\hline $\mathrm{CM} 25 / \mathrm{N}$ & Cattle Manure 25 ton ha ${ }^{-1}+1.85 \mathrm{~g} \mathrm{~N}$ pot $^{-1}$ \\
\hline
\end{tabular}

\section{B. Cultivation and Fertilizer Application.}

Green mustard seeds were first soaked in water for 24 hours to allow the seeds to absorb the moisture required for sprouting. The seeds were removed from the water and wrapped in a wet paper. Mustard seeds were germinated in blue plastic case containing mixture of soil, cattle manure, and rice husk at ratio of 2:1:1 by volume, respectively. After 2 weeks when 2-3 leaves had emerged, germinate was transferred to the polybag. Two sprouts were planted per polybag and later thinned to one stand. Polybag were arranged randomly with spacing of $20 \mathrm{~cm} \times 20 \mathrm{~cm}$.

During the experiment, soil was maintained moist and watered when necessary. At the end of the experiment, soil sample was collected from each polybag. The soil, then, was air-dried, sieved with $0.5 \mathrm{~mm}$ screen and analyzed for total soil nitrogen using micro Kyldahl method.

Organic fertilizer (Litter Compost and Cattle Manure) was applied one week before planting at the rate as shown in Table I. Nitrogen fertilizer was applied one week after planting at the rate of $1.85 \mathrm{~g}$ per polybag.

\section{Data Collection and Statistical Analysis}

Green mustard was harvested 5 weeks after planting. Variables observed in this experiment included plant height, fresh weight, leaf area per plant, leaf greenness, root dry weight, and soil total nitrogen. All variables were measured at harvesting.

Statistical analysis was carried out using PROC GLM in Statistical Analysis System version 9.1.3 portable at $\mathrm{P}<5 \%$. Treatment means were separated using Duncan's Multiple Range Test (DMRT) at probability level of $5 \%$.

\section{RESULTS AND DISCUSSION}

Analysis of variance using 95\% confidence level shows that organic fertilizer with or without nitrogen fertilizer does not significantly influence total soil nitrogen, plant height, root dry weight, leaf area and leaf greenness of green mustard. Only are leaf number and plant fresh weight of green mustard affected by organic fertilizer either with or without nitrogen fertilizer (Table II). 
TABLE II.

ANOVA OF GROWTH AND YIELD COMPONENT VARIABLES OF GREEN MUSTARD

\begin{tabular}{|l|l|}
\hline Variables & Calculated F \\
\hline Plant height & $1.83 \mathrm{~ns}$ \\
\hline Leaf number & $3.56^{*}$ \\
\hline Fresh weight & $9.47^{*}$ \\
\hline Leaf area & $0.74 \mathrm{~ns}$ \\
\hline Root dry weight & $1.43 \mathrm{~ns}$ \\
\hline Leaf greenness & $1.85 \mathrm{~ns}$ \\
\hline
\end{tabular}

ns : non significant; $*$ : significantly different

Application of organic fertilizer with or without nitrogen fertilizer is capable to increase total nitrogen content in soil from $0.08 \%$ at pre-planting to $0.19-0.33 \%$ at harvesting, depending on each treatment. Upon decomposition, organic fertilizer will release nitrogen to soil solution and available for green mustard. Previous study showed that application of organic matter to soil increased availability of nitrogen, phosphorus, potassium, sulfur, and calcium for plant growth [17] [12]. Table III shows that total nitrogen content in soil is not significantly different among treatments. This is indicated that addition of nitrogen fertilizer does not provide significant contribution to the availability of nitrogen to green mustard.

TABLE III.

EFFeCt Of Organic FerTilizer AND Nitrogen On TOtaL SoIL Nitrogen, Plant HeIGHT, LEAF Number AND LEAF GREENNESS

\begin{tabular}{|c|c|c|c|c|c|}
\hline \multicolumn{2}{|c|}{ Treatment } & \multirow{2}{*}{$\begin{array}{c}\text { TSN } \\
(\%)\end{array}$} & \multirow{2}{*}{$\begin{array}{c}\mathrm{PH} \\
\left(\mathrm{g}_{\text {plant }}^{-1}\right)\end{array}$} & \multirow[t]{2}{*}{ LN } & \multirow[t]{2}{*}{ LG } \\
\hline $\begin{array}{l}\text { Compost } \\
\left(\mathrm{Mg} \mathrm{ha}^{-1}\right)\end{array}$ & $\begin{array}{c}\text { N Fertilizer } \\
\left(\mathrm{g} \mathrm{pot}^{-1}\right)\end{array}$ & & & & \\
\hline LC-25 & - & 0.21 & 19.02 & $10.8 \mathrm{bc}$ & 34.88 \\
\hline LC-15 & 1.85 & 0.19 & 29.19 & $10.9 \mathrm{bc}$ & 34.75 \\
\hline LC-20 & 1.85 & 0.21 & 29.65 & $11.7 \mathrm{ab}$ & 34.90 \\
\hline LC-25 & 1.85 & 0.33 & 30.75 & $12.0 \mathrm{a}$ & 35.58 \\
\hline CM-25 & - & 0.21 & 28.95 & $10.3 \mathrm{c}$ & 34.99 \\
\hline CM-15 & 1.85 & 0.20 & 29.90 & $11.1 \mathrm{abc}$ & 34.84 \\
\hline CM-20 & 1.85 & 0.22 & 29.60 & $11.4 \mathrm{ab}$ & 35.14 \\
\hline CM-25 & 1.85 & 0.32 & 30.85 & $11.9 \mathrm{a}$ & 35.33 \\
\hline
\end{tabular}

LC $=$ Litter compost CM = Cattle manure; TSN = Total soil nitrogen;

$\mathrm{PH}=$ Plant height; LN = Leaf number; LG = Leaf greenness; mean followed by the same letter within column is not significantly differences.

Treatment of organic fertilizer with or without addition of $\mathrm{N}$ does not provide significant different on plant height and leaf greenness (Table III). Similar finding was reported by [18] that application of Wedelia compost supplemented with $\mathrm{N}, \mathrm{P}$, and $\mathrm{K}$ fertilizer had no difference in plant height and leaf greenness.

Fertilization of litter compost at rate of $25 \mathrm{Mg} \mathrm{ha}^{-1}$ with addition of $1.85 \mathrm{~g} \mathrm{~N}$ fertilizer per plant results in $20.2 \%$ and $14.5 \%$ higher fresh weight per plant and leaf number of green mustard, respectively as compared to that at rate of 20 $\mathrm{Mg} \mathrm{ha}^{-1}$ with addition of $\mathrm{N}$ fertilizer. The same trend is observed for cattle compost application. Study by [19] also showed that organic fertilizer (chicken manure) significantly increased yield of lettuce until rate of $60 \mathrm{Mg} \mathrm{ha}^{-1}$. But, application of both organic fertilizers at rate of $25 \mathrm{Mg} \mathrm{ha}^{-1}$ without addition of nitrogen fertilizer as other treatments does not give significant differences on total soil nitrogen content, plant height, root dry weight, leaf area, and leaf greenness (Table III and IV). This indicates that nitrogen fertilizer can be reduced by applying organic fertilizer. Research on mustard showed that at least $25 \%$ of NPK fertilizer amount can be substituted by vermicompost. Combined application of different fertilizers has enhanced LAI, CGR, NAR, PR, LAD and HI of mustard crop plants [3]. It also reported that the Amaranthus yield in organo-mineral fertilizer (compost amended with mineral fertilizer) treatment was significantly higher than the yield obtained from NPK fertilizer or unamended compost [20].

Application of organic fertilizer with or without addition of nitrogen significantly increases leaf number of green mustard, but it is not followed by significant increase in leaf area and leaf greenness, indicating that green mustard with more leaves does not cause increase in leaf area. This might be related to narrow range of leaf number which is only 1012 leaves per plant (Table III). Similar finding was reported by [21] where $\mathrm{N}$ fertilizer increased number of leaves, leaf area, root length, root girth, fresh biomass and yield of radish. Application of compost $+50 \%$ recommended $\mathrm{N}$ fertilizer resulted in no significant different in all those variables compared to that of recommended $\mathrm{N}$ fertilizer. Those indicate that application of compost saved about $50 \%$ of the recommended $\mathrm{N}$ fertilizer.

TABLE IV.

EFFECT Of Organic Fertilizer AND Nitrogen On Fresh Wight, RoOT DRY WEIGHT AND LEAF AREA.

\begin{tabular}{|c|c|c|c|c|}
\hline \multicolumn{2}{|c|}{ Treatment } & \multirow{2}{*}{$\begin{array}{c}\mathrm{FW} \\
\left(\mathrm{g} \mathrm{plant}^{-1}\right)\end{array}$} & \multirow{2}{*}{$\begin{array}{c}\text { RDW } \\
\left(\text { g plant }^{-1}\right)\end{array}$} & \multirow{2}{*}{$\begin{array}{c}\mathrm{LA} \\
\left(\mathrm{cm}^{2}\right)\end{array}$} \\
\hline $\begin{array}{l}\text { Compost } \\
\left(\mathrm{Mg} \mathrm{ha}^{-1}\right)\end{array}$ & $\begin{array}{c}\text { N Fertilizer } \\
\left(\mathrm{g} \mathrm{pot}^{-1}\right)\end{array}$ & & & \\
\hline LC-25 & - & $25.62 \mathrm{~b}$ & 0.80 & 116.04 \\
\hline LC-15 & 1.85 & $26.55 \mathrm{~b}$ & 0.86 & 116.15 \\
\hline LC-20 & 1.85 & $27.88 \mathrm{~b}$ & 0.91 & 116.34 \\
\hline LC-25 & 1.85 & $31.91 \mathrm{a}$ & 0.95 & 116.80 \\
\hline CM-25 & - & $25.90 \mathrm{~b}$ & 0.81 & 116.07 \\
\hline CM-15 & 1.85 & $25.61 \mathrm{~b}$ & 0.83 & 116.07 \\
\hline CM-20 & 1.85 & $27.18 \mathrm{~b}$ & 0.89 & 116.26 \\
\hline CM-25 & 1.85 & $30.94 \mathrm{a}$ & 0.99 & 116.82 \\
\hline
\end{tabular}

LC = Litter compost CM = Cattle manure; FW = Fresh weight RDW = Root dry weight; LA = Leaf area, mean followed by the same letter within column is not significantly differences.

\section{CONCLUSIONS}

It is obvious that the use of both litter compost and cattle manure have significantly similar contribution to the growth and yield of green mustard. Fertilization of litter compost and cattle manure at rate of $25 \mathrm{Mg} \mathrm{ha}^{-1}$ with additional nitrogen fertilizer produces higher green mustard fresh weight and number of leaves. Nevertheless, application of both organic fertilizers at rate $25 \mathrm{Mg} \mathrm{ha}^{-1}$ without additional nitrogen fertilizer as other treatments does not give significant differences on most variables, suggesting that application of organic fertilizer on green mustard is able to lessen nitrogen fertilizer. 


\section{REFERENCES}

[1] Z. Muktamar, S. Sujatmiko, B. Toha, and M. Asteria, "Farmers are sucrificing their health for production of vegetables," In Proc. International Conference on Sustainable Agriculture and Food Security: Challenges and Opportunities, 2012, pp. 141-149.

[2] A.E. Russell, D.A. Laird, and A. P. Mallarino, "Nitrogen fertilization and cropping system impacts on soil quality in Midwestern Mollisols," Soil Sci. Soc. Am. J. vol 70, no 1 pp 249255, 2006.

[3] T. Mondal, J.K. Datta, and N.K. Mondal, "Chemical fertilizer in conjunction with biofertilizer and vermicompost induced changes in morpho-physiological and bio-chemical traits of mustard crop," (in press). Journal of the Saudi Society of Agricultural Sciences. http://dx.doi.org/10.1016/j.jssas.2015.05.00, 2015.

[4] M. D. Taylor, "Accumulation of cadmium derived from fertiisers in New Zealand soils," Science of the Total Environment, vol 208, no 1-2, pp. 64-68, 1997.

[5] V. Satyanarayana, P.V.V. Prasad, V.R.K. Murthy and K.J. Boote, "Influence of integrated use of farmyard manure and inorganic fertilizers on yield and yield components of irrigated lowland rice," Ind. J. Plant Nutr., no 25 pp 2081-2090, 2002.

[6] S.K. Rautaray, B.C. Ghosh and B.N. Mittra, "Effect of fly ash, organic wastes and chemical fertilizers on yield, nutrient uptake, heavy metal content and residual fertility in a rice-mustard cropping sequence under acid lateritic soils,: Biores. Tech. no 90, pp 275-283, 2003.

[7] Aminuddin, "Various fertilizer effects on home garden," Available: http://www.extension.usu.edu/files/publications/vegetablepr.pdf 1995, downloaded October, 2004.

[8] C. Rivero, T. Chirenje, L. Q. Ma, and G. Martinez, "Influence of compost on soil organic matter quality under tropical conditions," Geoderma no 123, pp 355-361, 2004.

[9] J.W. Singer, R. W. Malone, M. D. Tomer, T. G. Meade, and J. Welch, "Compost effect on water retention and native plant establishment on a construction embankment," J. Soil and Water Conservation vol 61, no 5, pp 268-273. 2006

[10] J. Lehmann, J. Kinyangi, and D. Solomon, "Organic matter stabilization in soil micro-aggregtes: Implication from spatial heterogeneity of organic carbon contents and carbon form," Biogeochemistry no 85, pp 45-57, 2007.

[11] K.D. Smiciklas, P. M. Walker and T.R. Kelley, "Evaluation of compost for use as a soil amendment in corn and soybean production," Compost Science \& Utilization vol 16, no 3, pp 183191, 2008.
[12] A.O. Shokalu, A.O. Ojo, D.T. Ezekiel-Adewoyin, A. H. Akinwunmi, and J. O. Azees, "Comparing the use of Tithonia diversifolia and Compost as soil amendments for growth and yield of Celosia argentea," New York Science J. vol 3, no 6, pp134-138, 2010.

[13] V.T. Guong, N. X. Hien and D. Minh, "Effect of fresh and composted organic amendment on soil compaction and soil biochemical properties of citrus orchards in the Mekong Delta, Vietnam," In Proc of 19th World Congress of Soil Science, Soil Solutions for a Changing World. 1 - 6 August 2010, Brisbane, Australia. 2010.

[14] S. Brown and M. Cotton, "Changes in soil properties and carbon content following compost application: Results of on-farm sampling," Compost Science \& Utilization vol 19, no 2, pp 87-96, 2011.

[15] Z. Muktamar, S.K.Y. Hasibuan, D. Suryati. And N. Styowati "Column study of nitrate downward movement and selected soil chemical properties' change as influenced by liquid organic fertilizer" Journal of Agricultural Technology vol 11 no 8 pp. 20172027. 2015.

[16] N. Setyowati , Z. Muktamar, B. Suriyanti, and M. Simarmata, "Growth and yield of chili pepper as affected by weed based organic compost and nitrogen fertilizer," Int J. on Advance Science Engineering Information Technology. Vol 4, no 2, pp 84-87, 2014.

[17] M.S. Ullah, M. S. Islam, M. A. Islam, and T. Huque, "Effects of organic manures and chemical fertilizers on the yield of brinjal and soil properties," J. Bangladesh Agril. Univ. vol 6, no 2, pp 271-276, 2008.

[18] N. Setyowati, Z. Muktamar, I. Puspitasari."Weed based organic fertilizer to reduce application of synthetic fertilizer ins mustard (Brassica sinensis L.). J. Agricultural Technology vol 11 no 8 pp 1677-1683. 2015.

[19] M.T. Masarirambi, P. Dlamini, P. K. Wahome, and T. O. Oseni, "Effects of chicken manure on growth, yield and quality of lettuce (Lactuca sativa L.) 'Taina' under a Lath House in a semi-arid subtropical environment," American-Eurasian J. Agric. \& Environ. Sci., vol 12, no 3, pp 399-406, 2012.

[20] O.A. Abayomi and O. J. Adebayo, "Effect of fertilizer types on the growth and yield of Amaranthus caudatus in Ilorin, Southern Guinea, Savanna Zone of Nigeria," Advances in Agriculture. Volume 2014. Article ID 947062. http://dx.doi.org/10.1155/2014/947062, 2014.

[21] H. N. Asghar, M. Ishaq, Z.A. Zahir, M. Khalid and M. Arshad, "Response of radish to integrated use of nitrogen fertilizer and recycled organic waste," Pak. J. Bot., vol 38, no 3, pp 691-700, 2006. 